\title{
UPAYA MENINGKATKAN KEMAMPUAN MEMBACA PERMULAAN MELALUI PERMAINAN KARTU HURUF SISWA KELAS 1 DI UPTD SDN 01 TALANG ANAU TAHUN PELAJARAN 2020/2021
}

\author{
Sendrawati \\ UPTD SD Negeri 01 Taalang Anau, Kecamatan Gunuang Omeh, Kabupaten Lima Puluh Kota \\ sendrawati385@gmail.com
}

\begin{abstract}
This study aims to improve early reading skills through letter card games for grade 1 students at UPTD SDN 01 Talang Anau. This type of research is Classroom Action Research (CAR). The subjects in this study were grade 1 students of UPTD SDN 01 Talang Anau which consisted of 15 students. This research was conducted in three cycles and each cycle through four stages which include: (1) planning, (2) implementation, (3) observation, (4) reflection. The instruments used in this study were the initial reading ability test, observation sheets for teacher and student activities. The results showed that there was an increase in initial reading ability for each cycle. The percentage of students who succeed $46.67 \%$ in the first cycle, $66.67 \%$ in the second cycle, and $86.67 \%$ in the third cycle. So it can be concluded that the early reading ability of grade 1 students of UPTD SDN 01 Talang Anau can be improved through letter card games.
\end{abstract}

Keywords: Beginning Reading Ability, Letter Card Game.

\begin{abstract}
Abstrak
Penelitian ini bertujuan untuk meningkatkan kemampuan membaca permulaan melalui permainan kartu huruf siswa kelas 1 di UPTD SDN 01 Talang Anau. Jenis penelitian ini adalah Penelitian Tindakan Kelas (PTK). Subjek dalam penelitian ini yaitu siswa kelas 1 UPTD SDN 01 Talang Anau yang terdiri dari 15 orang siswa. Penelitian ini dilakukan dalam tiga siklus dan masing-masing siklus melalui empat tahap yang mencakup: (1) perencanaan, (2) pelaksanaan, (3) observasi, (4) refleksi. Instrumen yang digunakan dalam penelitian ini yaitu tes kemampuan membaca permulaan, lembar pengamatan aktivitas guru dan siswa. Hasil penelitian menunjukkan peningkatan kemampuan membaca permulaan siswa pada setiap siklus. Persentase siswa yang yang tuntas yaitu sebesar $46,67 \%$ pada siklus I, $66,67 \%$ pada siklus II, dan $86,67 \%$ pada siklus III. Sehingga dapat disimpulkan bahwa kemampuan membaca permulaan siswa kelas 1 UPTD SDN 01 Talang Anau dapat ditingkatkan melalui permainan kartu huruf.
\end{abstract}

Kata Kunci: Kemampuan Membaca Permulaan, Permainan Kartu Huruf.

\section{PENDAHULUAN}

Bahasa Indonesia sangat memegang peranan penting dalam peningkatan mutu pendidikan pada Sekolah Dasar (SD). Bahasa Indonesia juga merupakan bahasa pengantar dalam dunia pendidikan. Oleh karena itu, siswa harus menguasai semua kemampuan bahasa dengan baik. Tarigan (2008:1) menjelaskan bahwa kemampuan berbahasa mempunyai empat komponen, yaitu 1) kemampuan 
menyimak; 2) kemampuan berbicara; 3) kemampuan membaca; dan 4) kemampuan menulis. Keempat kemampuan tersebut saling berkaitan satu sama lain. Kemampuan membaca merupakan satu dari empat kemampuan berbahasa. Pentingnya kemampuan membaca dikuasai peserta didik, karena kemampuan ini menjadi dasar untuk memahami semua pembelajaran.

Pembelajaran membaca disekolah dasar sesuai dengan tahapan menurut kelompok kelas rendah dan kelas tinggi. Untuk siswa kelas rendah tahapan membacanya adalah membaca permulaan.Membaca permulaan pada siswa kelas rendah merupakan fondasi dari tahapan membacacepat, membaca ekstensif dan membaca pemahaman.Guru harus benar-benar mengasah kemampuan membaca permulaan siswa.

Kemampuan membaca sangat diperlukan untuk memperluas pengetahuan dan pengalaman serta untuk mempertajam penalaran untuk meningkatkan diri seseorang. Apabila anak pada usia sekolah tidak segera memiliki kemampuan membaca, maka ia akan mengalami banyak kesulitan dalam mempelajari berbagai bidang studi pada kelas-kelas berikutnya. Kemampuan membaca dikelas rendah sangat berperan penting sebagai fondasi atau dasar penentu keberhasilan dalam kegiatan belajar siswa. Jika pembelajaran membaca dikelas rendah tidak kuat, pada tahap membaca lanjutan siswa akan sulit memiliki kemampuan membaca yang memadai.

Membaca permulaan merupakan tahapan belajar membaca bagi siswa sekolah dasar kelas rendah atau kelas awal yaitu kelas I dan II. Tujuannya adalah agar siswa memiliki kemampuan memahami dan menyuarakan tulisan dengan intonasi yang wajar sebagai dasar untuk dapat membaca lanjut. Menurut Zuchdi dan Budiasih (2001:58) materi yang diajarkan dalam membaca permulaan yakni, Lafal dan intonasi kata dan kalimat sederhana, Katakata baru yang bermakna, menggunakan huruf- huruf yang sudah dikenal Lafal dan intonasi kata yang sudah dikenal dan kata baru.

Tujuan membaca permulaan adalah: 1) pembinaan dasar-dasar mekanisme membaca, 2) mampu memahami dan menyuarakan kalimat sederhana yang diucapakan dengan intonasi yang wajar, 3) membaca kalimat sederhana dengan lancar dan tepat. Hal tersebut menggambarkan bahwa membaca permulaan diperlukan supaya siswa mampu memahami dan mengucapkan tulisan dengan lafal dan intonasi yang jelas. Membaca permulaan dapat membantu siswa dalam memahami suatu teks bacaan.

Diharapkan siswa mendapat informasi dari bacaan tersebut sehingga menambah pengetahuan.Membaca permulaan pada siswa kelas 1 harus memdapat perhatian penuh dari guru.Pada tahap ini, siswa kelas I mulai mengenal huruf, bunyi, kata, suku kata, dan kalimat meskipun dalam lingkup sederhana. Guru berperan penting dalam membimbing siswa agar mampu membaca.

Ada beberapa faktor yang dapat mempengaruhi keterampilan membaca siswa, baik faktor dari dalam maupun faktor dari luar. Salah satunya motivasi dan bahan bacaan, motivasi merupakan faktor yang cukup besar mempengaruhi keterampilan membaca, apabila seseorang tidak memiliki motivasi maka akan mengakibatkan enggan membaca, sedangkan yang memiliki motivasi tinggi akan memiliki dorongan yang cukup kuat untuk membaca.

Berdasarkan hasil refleksi awal yang peneliti lakukan terlihat terdapat beberapa permasalahan berkaitan dengan membaca permulaan pada siswa kelas I 
UPTD SDN 01 Talang Anau yaitu rendahnya kemampuan membaca permulaan siswa. Sehingga diperlukan suatu tindakan untuk mengatasi permasalahan tersebut.

Media yang digunakan dalam pelajaran juga akan mempengaruhi minat belajar siswa. Bahan bacaan sebagai media seharusnya mampu menarik minat siswa untuk membaca. Bahan bacaan yang terlalu sulit dipahami akan membuat seseorang untuk enggan membaca. Pembelajaran membaca yang dapat memberikan pengalaman pada siswa yaitu dengan melibatkan langsung siswa pada proses pembelajaran seperti permainan bahasa dan pemakaian media yang dapat melibatkan siswa. Salah satu media yang dapat digunakan dalam pembelajaran membaca permulaan yaitu media kartu huruf. Azhar Arsyad (2005:119) mengungkapkan bahwa kartu huruf atau yang disebut dengan kartu abjad merupakan salah satu bentuk dari flash card yaitu merupakan kartu kecil yang berisi gambar, huruf, teks atau tanda simbol yang mengingatkan atau menuntun siswa kepada sesuatu yang berhubungan dengan simbol-simbol tersebut.

Masalah tentang rendahnya kemampuan membaca kelas 1 harus di atasi agar siswa tidak mengalami kesulitan dalam hal membaca permulaan. Maka melalui permainan kartu huruf diharapkan dapat meningkatkan ketertarikan dan kemampuan siswa khususnya dalam membaca permulaan. Maka dalam penelitian ini peneliti mengangkat judul "Upaya Meningkatkan Kemampuan Membaca Permulaan Melalui Permainan Kartu Huruf Siswa Kelas I di UPTD SDN 01 Talang Anau Tahun Pelajaran 2020/2021". Tujuan dari penelitian ini adalah untuk mengetahui penggunaan permainan kartu huruf dalam meningkatkan kemampuan membaca permulaan siswa kelas 1 di UPTD SDN 01 Talang Anau tahun pelajaran 2020/2021.

\section{METODOLOGI PENELITIAN}

Penelitian yang dilakukan adalah penelitian tindakan kelas tujuannya untuk memperdalam pemahaman dan memperbaiki tindakan dalam proses belajar mengajar. Arikunto (2010:3) menjelaskan bahwa penelitian tindakan kelas merupakan suatu pencermatan terhadap kegiatan belajar berupa sebuah tindakan, yang sengaja dimunculkan dan terjadi dalam sebuah kelas secara bersama. Penelitian ini berusaha untuk mendeskripsikan peningkatan kemampuan membaca permulaan siswa kelas 1 UPTD SDN 01 Talang Anau dengan menerapkan permainan kartu huruf. Subyek penelitian ini adalah siswa kelas 1 UPTD SD Negeri 01 Talang Anau sebanyak 15 siswa tahun pelajaran 2020/2021.

Prosedur penelitian ini mengembangkan sebagaimana lazimnya dalam penelitian tindakan yaitu berbentuk siklus. Tiap siklus dalam Penelitian Tindakan Kelas (PTK) ini terdiri dari perencanaan, pelaksanaan, pengamatan atau observasi dan refleksi. Hasil refleksi akan digunakan sebagai pertimbangan dalam membuat rencana bagi siklus berikutnya jika ternyata tindakan yang dilakukan belum berhasil, demikian seterusnya hingga mencapai hasil yang ditetapkan. Secara prosedural tahapan di atas dapat digambarkan sebagai berikut :

1. Tahap Perencanaan Tindakan

Tahap pertama dalam melakukan penelitian yaitu diawali dengan identifikasi masalah yang berkaitan dengan kesiapan membaca permulaan, kemudian merumuskan masalah tersebut dan dianalisis penyebab masalah itu 
terjadi.Pada tahap ini peneliti menyusun scenario dan perencanaan pembelajaran dengan menggunakan media kartu huruf bergambar, membuat format observasi kemudian terakhir evaluasi.

2. Tahap Pelaksanaan Tindakan

Pada tahap ini, peneliti akan menjadi pelaksana dalam penelitian ini. Penelitia akan melaksanakan pembelajaran sesuai dengan RPP yang telah disusun yaitu dengan menggunakan media kartu huruf untuk meningkatkan kemampuan membaca permulaan siswa.

3. Tahap Observasi / Pengamatan

Pada tahap ini dilakukan pengumpulan data dengan melakukan pengamatan menggunakan instrumen data untuk mengukur kesiapan membaca permulaan siswa melalui kartu huruf.

4. Tahap Refleksi

Setelah semua data terkumpul, tahapan selanjutnya yaitu analisis dan yang dapat memberikan arahan perbaikan untuk siklus selanjutnya. Tahap ini mengulas secara reflektif tentang perubahan yang terjadi pada peserta didik, guru dan suasana kelas.

Teknik analisis data yang digunakan yaitu teknik persentase. Indikator keberhasilan penelitian yaitu jika persentase kemampuan membaca permulaan siswa lebih dari $75 \%$ maka penelitian dikatakan berhasil. Jika tidak penelitian perlu dilanjutkan ke siklus berikutnya.

\section{HASIL PENELITIAN DAN PEMBAHASAN \\ Hasil Penelitian \\ Pra Siklus}

Hasil refleksi awal peneliti, diperoleh data kemampuan awal sebelum tindakan. Kemampuan membaca permulaan siswa pada prasiklus diperoleh seperti pada tabel berikut.

Tabel 1. Kondisi Awal Kemampuan Membaca Permulaan Siswa

\begin{tabular}{|l|l|l|l|}
\hline No & Nama Siswa & Nilai & Kriteria \\
\hline 1 & SIFA & 65 & Tidak Tuntas \\
\hline 2 & DAFA & 75 & Tuntas \\
\hline 3 & RAFA & 60 & Tidak Tuntas \\
\hline 4 & AFA & 75 & Tuntas \\
\hline 5 & CAHAYA & 65 & Tidak Tuntas \\
\hline 6 & AMANDA & 60 & Tidak Tuntas \\
\hline 7 & GISTI & 65 & Tidak Tuntas \\
\hline 8 & NABILA & 60 & Tidak Tuntas \\
\hline 9 & MUTIARA & 75 & Tuntas \\
\hline 10 & AZKA & 55 & Tidak Tuntas \\
\hline 11 & IQMAL & 75 & Tuntas \\
\hline 12 & ZIQLI & 65 & Tidak Tuntas \\
\hline 13 & RISKI & 65 & Tidak Tuntas \\
\hline 14 & ZAKIA & 65 & Tidak Tuntas \\
\hline 15 & PANJI & 80 & Tuntas \\
\hline Jumlah & & 1005 & \\
\hline Nilai Rata-rata siswa & 67,00 & \\
\hline
\end{tabular}




\begin{tabular}{|l|l|}
\hline Jumlah siswa yang berhasil & 5 \\
\hline Persentase keberhasilan siswa & $33,33 \%$ \\
\hline Jumlah siswa yang belum berhasil & 10 \\
\hline Persentasi siswa yang belum berhasil & $66,67 \%$ \\
\hline
\end{tabular}

Data dalam tabel 1 di atas terlihat hasil belajar siswa masih dalam kondisi rendah. Jumlah siswa yang berhasil hanya 5 orang atau 33,33\% dari jumlah keseluruhan siswa 15 orang, sedangkan jumlah siswa yang belum berhasil sebanyak 15 orang atau $66,67 \%$ dari jumlah keseluruhan. Selain itu nilai rata-rata yang diperoleh siswa juga masih rendah yaitu 65. Dari sinilah peneliti melakukan penelitian tindakan kelas guna untuk memperbaiki pembelajaran dan meningkatkan hasil belajar siswa dalam membaca permulaan di kelas 1 melalui permainan kartu huruf.

\section{Siklus I}

1. Perencanaan (Planning)

Pada tahap perencanaan siklus I dilakukan kegiatan sebagai berikut:

a. Identifikasi masalah yang ada dikelas

b. Merancang RPP sesuai dengan permainan kartu huruf.

c. Merancang Instrumen penelitian yaitu lembar observasi aktivitas guru, lembar observasi aktivitas siswa, dan tes kemampuan membaca permulaan.

d. Mempersiapkan media kartu huruf yang akan digunakan.

2. Pelaksanaan

Pada tahap ini, pelaksanaan tindakan tergambar di dalam Rencana Pelaksanaan Pembelajaran (RPP). Peneliti melaksanakan tindakan sebanyak dua kali pertemuan dan satu kali tes di akhir siklus I.

3. Observasi.

Pengamatan atau observasi merupakan pengambilan data yang dilakukan pada saat kegiatan pembelajaran berlangsung. Obervasi selama pembelajaran berlangsung dibantu oleh salah seorang teman sejawat pada setiap pertemuan yaitu Ibu Farida, S.Pd. Lembar observasi dilakukan pengisian oleh observer pada setiap pertemuan. Hasil lembar observasi menunjukkan bahwa aktivitas guru pada setiap pembelajaran sudah baik. Sementara itu aktivitas siswa masih cukup baik.

Di akhir siklus I dilaksanakan tes kemampuan membaca permulaan. Hasil tes dapat dilihat pada tabel 2 berikut.

Tabel 2. Kemampuan Membaca Peermulaan Siklus I

\begin{tabular}{|l|l|l|l|}
\hline No & Nama Siswa & Nilai & Kriteria \\
\hline 1 & SIFA & 65 & Tidak Tuntas \\
\hline 2 & DAFA & 75 & Tuntas \\
\hline 3 & RAFA & 60 & Tidak Tuntas \\
\hline 4 & AFA & 80 & Tuntas \\
\hline 5 & CAHAYA & 65 & Tidak Tuntas \\
\hline 6 & AMANDA & 60 & Tidak Tuntas \\
\hline 7 & GISTI & 70 & Tuntas \\
\hline 8 & NABILA & 60 & Tidak Tuntas \\
\hline
\end{tabular}




\begin{tabular}{|c|c|c|c|}
\hline 9 & MUTIARA & 75 & Tuntas \\
\hline 10 & AZKA & 60 & Tidak Tuntas \\
\hline 11 & IQMAL & 75 & Tuntas \\
\hline 12 & ZIQLI & 70 & Tuntas \\
\hline 13 & RISKI & 70 & Tuntas \\
\hline 14 & ZAKIA & 65 & Tidak Tuntas \\
\hline 15 & PANJI & 80 & Tuntas \\
\hline \multicolumn{2}{|c|}{ Jumlah } & \multicolumn{2}{|l|}{1025} \\
\hline \multicolumn{2}{|c|}{ Nilai Rata-rata siswa } & \multicolumn{2}{|l|}{68,33} \\
\hline \multicolumn{2}{|c|}{ Jumlah siswa yang berhasil } & \multicolumn{2}{|l|}{7} \\
\hline \multicolumn{2}{|c|}{$\begin{array}{l}\text { Persentase keberhasilan } \\
\text { siswa }\end{array}$} & \multicolumn{2}{|l|}{$46,67 \%$} \\
\hline \multicolumn{2}{|c|}{$\begin{array}{l}\text { Jumlah siswa yang belum } \\
\text { berhasil }\end{array}$} & \multicolumn{2}{|l|}{8} \\
\hline \multicolumn{2}{|c|}{$\begin{array}{l}\text { Persentasi siswa yang belum } \\
\text { berhasil }\end{array}$} & \multicolumn{2}{|l|}{$53,33 \%$} \\
\hline
\end{tabular}

Dari tabel di atas dapat diketahui nilai rata-rata siswa masih rendah dan belum memenuhi KKM. Hal ini terlihat dari rendahnya nilai rata-rata yang diperoleh siswa pada Siklus I yaitu 68,33. Jumlah siswa yang berhasil hanya 7 orang atau $46,67 \%$ dari jumlah keseluruhan siswa dan siswa yang belum berhasil sebanyak 8 siswa atau 53,33 \% dari seluruh siswa, artinya sudah ada peningkatan sari hasil belajar pada siklus I ini jika dibandingkan dengan nilai prasiklus, namun belum memenuhi target yang diinginkan peneliti, yaitu siswa berhasil sebanyak $75 \%$ dari jumlah keseluruhan siswa. Oleh karena itu tindakan dilanjutkan pada siklus II.

4. Refleksi

Berdasarkan hasil observasi yang merupakan gambaran aktivitas siswa selama proses pembelajaran berlangsung, secara keseluruhan aktivitas siswa belum berlangsung masih cukup baik. Aktivitas guru sudah baik pada siklus I. Dilihat dari kemampuan membca permulaan siswa hanya 46,67\% siswa yang tuntas. Sehingga penelitian dilanjutkan ke siklus II karena indikator keberhasilan belum tercapai.

\section{Siklus II}

1. Perencanaan (Planning)

Pada tahap perencanaan siklus II dilakukan kegiatan sebagai berikut:

a. Merancang RPP

b. Merancanag Instrumen penelitian yaitu lembar observasi aktivitas guru, lembar observasi aktivitas siswa, dan tes kemampuan membaca permulaan.

c. Mempersiapkan media kartu huruf.

2. Pelaksanaan

Siklus II dilaksanakan sebanyak dua kali perteuan dan satu kali tes. Pada tahap ini, pelaksanaan tindakan tergambar di dalam Rencana Pelaksanaan Pembelajaran (RPP). Peneliti melaksanakan pembelajaran sesuai dengan langkah-langkah yang ada pada RPP. 
3. Observasi.

Pengamatan atau observasi merupakan pengambilan data yang dilakukan pada saat kegiatan pembelajaran berlangsung. Lembar observasi dilakukan pengisian oleh observer yaitu Ibu Farida, S.Pd. pada setiap pertemuan. Hasil analisis menunjukkan bahwa aktivitas siswa pada saat pembelajaran siklus II sudah baik. Dan aktivitas guru juga sudah baik. Hasil tes kemampuan membca permulaan siswa pada siklus II dapat dilihat pada Tabel 3 berikut ini.

Tabel 3. Kemampuan Membaca Permulaan Siklus II

\begin{tabular}{|l|l|l|l|}
\hline No & Nama Siswa & Nilai & Kriteria \\
\hline 1 & SIFA & 70 & Tuntas \\
\hline 2 & DAFA & 80 & Tuntas \\
\hline 3 & RAFA & 70 & Tuntas \\
\hline 4 & AFA & 85 & Tuntas \\
\hline 5 & CAHAYA & 75 & Tuntas \\
\hline 6 & AMANDA & 65 & Tidak Tuntas \\
\hline 7 & GISTI & 65 & Tuntas \\
\hline 8 & NABILA & 75 & Tuntas \\
\hline 9 & MUTIARA & 75 & Tuntas \\
\hline 10 & AZKA & 60 & Tidak Tuntas \\
\hline 11 & IQMAL & 80 & Tuntas \\
\hline 12 & ZIQLI & 80 & Tuntas \\
\hline 13 & RISKI & 65 & Tidak Tuntas \\
\hline 14 & ZAKIA & 65 & Tidak Tuntas \\
\hline 15 & PANJI & 80 & Tuntas \\
\hline Jumlah & 1090 & \\
\hline Nilai Rata-rata siswa & 72,67 & \\
\hline Jumlah siswa yang berhasil & 10 & \\
\hline Persentase keberhasilan siswa & $66,67 \%$ & \\
\hline $\begin{array}{l}\text { Jumlah siswa yang belum } \\
\text { berhasil }\end{array}$ & 5 & \\
\hline $\begin{array}{l}\text { Persentasi siswa yang belum } \\
\text { berhasil }\end{array}$ & $33,33 \%$ & \\
\hline
\end{tabular}

Dari tabel 3 di atas dapat diketahui nilai rata-rata siswa sudah cukup memenuhi KKM. Hal ini terlihat dari tercapainya niai rata-rata yang diperoleh siswa pada siklus II yaitu 72,67. Jumlah siswa yang berhasil sebanyak 10 orang atau 66,67 \% dari jumlah keseluruhan siswa dan yang belum berhasil sebanyak 5 orang atau 33,33\% dari jumlah keseluruhan siswa, artinya sudah terjadi peningkatan yang signifikan dari hasil belajar pada siklus II ini jika dibandingkan dengan nilai siklus I.

4. Refleksi

Berdasarkan hasil observasi yang merupakan gambaran aktivitas siswa selama proses pembelajaran berlangsung pada siklus II, secara keseluruhan aktivitas siswa berlangsung sudah baik. Aktivitas guru sudah sangat baik pada siklus II. Berdasarkan analisis kemampuan membaca permulaan siswa pada siklus II diperoleh persentase ketuntasan yaitu sebesar 66,67\%. Hasil ini telah mengalami kenaikan dari siklus $\mathrm{I}$, tetapi belum mencapai indikator 
keberhasilan penelitian yang telah ditetapkan sehingga penelitian dilanjutkan ke siklus III.

\section{Siklus III}

1. Perencanaan (Planning)

Perencanaan pembelajaran siklus III hamper sama dengan siklus sebelumnya. Peneliti melakukan perencanaan penyusunan RPP sesuai dengan materi. Mempersipakan instrumen penelitian yang dibutuhkan yaitu lembar observasi aktivitas guru, lembar observasi aktivitas siswa, dan tes kemampuan membaca permulaan. Dan mempersiapkan meida kartu huruf yang dibutuhkan sesuai dengan tema atau materi pada siklus III.

2. Pelaksanaan

Pada siklus III penelitian dilaksankan sebanyak 2 kali pertemuan dan satu kali tes kemampuan membaca permulaan. Pada tahap ini, pelaksanaan tindakan tergambar di dalam Rencana Pelaksanaan Pembelajaran (RPP) yang telah disusun..

3. Observasi.

Pengamatan atau observasi merupakan pengambilan data yang dilakukan pada saat kegiatan pembelajaran berlangsung. Lembar observasi dilakukan pengisian oleh observer yaitu Ibu Farida, S.Pd. pada setiap pertemuan. Pada siklus III, aktivitas guru dan siswa sudah berada pada kategori sangat baik. Guru dan siswa sudah sangat terbiasa dengan pembelajaran menggunakan media kartu huruf. Hasil analisis tes kemampuan membaca permulaan siswa dapat dilihat pada tabel 4 berikut.

Tabel 4. Kemampuan Membaca Permulaan Siklus III

\begin{tabular}{|l|l|l|l|}
\hline No & Nama Siswa & Nilai & Kriteria \\
\hline 1 & SIFA & 80 & Tuntas \\
\hline 2 & DAFA & 75 & Tuntas \\
\hline 3 & RAFA & 80 & Tuntas \\
\hline 4 & AFA & 80 & Tuntas \\
\hline 5 & CAHAYA & 75 & Tuntas \\
\hline 6 & AMANDA & 80 & Tuntas \\
\hline 7 & GISTI & 80 & Tuntas \\
\hline 8 & NABILA & 65 & Tidak Tuntas \\
\hline 9 & MUTIARA & 75 & Tuntas \\
\hline 10 & AZKA & 60 & Tidak Tuntas \\
\hline 11 & IQMAL & 80 & Tuntas \\
\hline 12 & ZIQLI & 75 & Tuntas \\
\hline 13 & RISKI & 70 & Tuntas \\
\hline 14 & ZAKIA & 80 & Tuntas \\
\hline 15 & PANJI & 80 & Tuntas \\
\hline Jumlah & 1135 & \\
\hline Nilai & Rata-rata siswa & 75,67 & \\
\hline Jumlah siswa yang berhasil & 13 & \\
\hline Persentase keberhasilan siswa & $86,67 \%$ & \\
\hline $\begin{array}{l}\text { Jumlah siswa yang belum } \\
\text { berhasil }\end{array}$ & 2 & \\
\hline
\end{tabular}




\begin{tabular}{l|l}
\hline $\begin{array}{l}\text { Persentasi siswa yang belum } \\
\text { berhasil }\end{array}$ & $13,33 \%$ \\
\hline
\end{tabular}

Dari tabel di atas terlihat bahwa hasil belajar siswa mengalami peningkatan secara signifikan, jika dibandingkan dengan hasil belajar pada sebelumnya karena siswa yang tuntas dalam belajar 13 orang atau 86,67\% dari keseluruhan siswa, sedangkan jumlah siswa yang tidak tuntas dalam belajar berjumlah 2 orang siswa atau $13,33 \%$. KKM yang telah ditentukan adalah 70 .

4. Refleksi

Hasil observasi pada saat siklus III berlangsung pada setiap pertemuan aktivitas siswa selama proses pembelajaran sudah sangat baik. Jiak ditinjau dari aktivitas guru juga sudah sudah sangat baik pada siklus III. Haisl tes menunjukkan bahwa kemampuan membca permulaan siswa pada siklus III diperoleh persentase ketuntasan yaitu sebesar $86,67 \%$. Hasil ini telah mengalami kenaikan dari siklus II dan telah mencapai indikator keberhasilan penelitian yang telah ditetapkan. Karena telah mencapai indikator keberhasilan penelitian yang telah ditetapkan maka penelitian ini dikatakan telah berhasil dan tidak perlu dilanjutkan ke siklus berikutnya.

\section{Pembahasan}

Penelitian Tindakan Kelas (PTK) dilaksanakan pada kelas I UPTD SDN 01 Talang Anau dalam tiga siklus, masing-masing siklus terdapat empat tahap yaitu perencanaan, pelaksanaan, observasi dan hasil refleksi tindakan. Rekapitulasi hasil belajar dan aktivitas siswa dari siklus I hingga siklus III dapat dilihat pada tabel 5 dibawah ini :

Tabel 5. Rekapitulasi Kemmapuan Membaca Permulaan Siswa Pada Setiap Siklus

\begin{tabular}{|l|l|l|l|l|}
\hline \multirow{2}{*}{ No } & \multirow{2}{*}{ Aspek yang dinilai } & \multicolumn{3}{|c|}{ Jumlah atau Persentase } \\
\cline { 3 - 5 } & & Siklus I & Siklus II & Siklus III \\
\cline { 3 - 5 } & & Rata-rata & Rata-rata & Rata-rata \\
\hline 1 & Rata-rata & 68,33 & 72,67 & 75,67 \\
\hline 2 & Jumlah siswa yang tuntas & 7 & 10 & 13 \\
\hline 3 & Jumlah siswa yang tidak tuntas & 8 & 5 & 2 \\
\hline 4 & Persentase siswa yang berhasil & $46,67 \%$ & $66,67 \%$ & $86,67 \%$ \\
\hline 5 & $\begin{array}{l}\text { Persentase siswa yang tidak } \\
\text { berhasil }\end{array}$ & $53,33 \%$ & $33,33 \%$ & $13,33 \%$ \\
\hline
\end{tabular}

Berdasarkan hasil penelitian, ternyata hasil belajar siswa kelas I UPTD SDN 01 Talang Anau dapat meningkat melalui permainan kartu.Peningkatan ini terjadi pada setiap siklus tindakan. Pada siklus I hasil belajar siswa rata-rata 68,33, siklus II rata-rata 72,67 dan pada siklus III mencapai 75,67. Peningkatan hasil belajar tersebut mengidentifikasi adanya peningkatan kemampuan siswa dalam membaca permulaan. Peningkatan kemampuan membaca permulaan ini meliputi anak sudah mampu membaca gambar, mampu menunjukkan simbol huruf yang diminta, mampu menyebut simbol, mampu menyebut kata dan membunyikan simbol huruf yang ada dalam kata, mampu menghubungkan gambar dengan kata, mampu menyusun huruf menjadi kata yang bermakna serta mampu mengelompokkan huruf vokal dan konsonan. 
Peningkatan kemampuan membaca permulaan siswa karena siswa senang mengikuti pembelajaran dengan menggunakan permainan kartu huruf. Pembelajaran yang menyenangkan sambil bermain sesuai dengan usia siswa. Karena dengan menggunakan media permainan kartu huruf siswa belajar sambil bermain, media ini juga dilengakapi dengan gambar dan warna yang menarik sehingga semakin membuat siswa tertatrik untuk belajar membaca permulaan.

\section{KESIMPULAN DAN SARAN}

Berdasarkan hasil penelitian dan pembahasan dapat disimpulkan bahwa kemampuan membaca permulaan siswa kelas I di UPTD SDN 01 Talang Anau dapat ditingkatkan melalui permainan kartu huruf. Hasil penelitian menunjukkan bahwa terjadi kemampuan membaca permulaan sebesar $46,67 \%$ pada akhir siklus I, pada akhir siklus II mengalami peningkatan menjadi $66,67 \%$ dan pada akhir siklus III mengalami peningkatan menjadi $86,67 \%$.

Berdasarkan hasil pelaksanaan penelitian, ada beberapa saran yang dapat dilaksanakan untuk meningkatkan kemampuan membaca permulaan melalui metode permainan kartu huruf, yaitu sebagi berikut:

1. Bagi guru khususnya UPTD SDN 01 Talang Anau, Kec. Gunuang Omeh,bahwa permainan kartu huruf ini dapat digunakan sebagai upaya untuk meningkatkan kemampuan membaca permulaan siswa. Kartu yang digunakan dibuat lebih besar dan menggunakan gambar-gambar yang lebih dikenali siswa sehingga dapat mempermudah siswa.

2. Bagi sekolah khususnya UPTD SDN 01 Talang Anau Kec. Gunuang Omeh, perlu menambah berbagai sumber kegiatan yang menarik untuk siswa dan menyediakan fasilitas yang dibutuhkan misalnya buku-buku kumpulan permainan untuk anak, sehingga metode pembelajaran yang ada juga dapat lebih variatif.

\section{DAFTAR PUSTAKA}

Arikunto, Suharsimi. 2010. Penelitian Tindakan Kelas. Jakarta: PT. Bumi Aksara. Arsyad, Azhar. 2007. Media Pembelajaran. Jakarta: PT. Raja Grafindo

Tarigan, Henry Guntur. 2008. Menulis: Sebagai suatu Keterampilan Berbahasa. Bandung: Angkasa.

Zuchdi, Darmiyati dan Budiasih. 2001. Pendidikan Bahasa dan Sastra Indonesia di Kelas Rendah. Yogyakarta: PAS 